\title{
Philanthropy and Community Development: the vital signs of community foundation?
}

\author{
Jenny Harrow \\ Centre for Charitable Giving and Philanthropy \\ Cass Business School \\ City University London \\ London, EC1Y8TZ \\ UK \\ j.harrow@city.ac.uk \\ Tobias Jung \\ School of Management \\ University of St Andrews \\ St Andrews, Fife, KY16 9RJ \\ Scotland, UK \\ tj3@st-andrews.ac.uk
}

Corresponding author: j.harrow@ city.ac.uk 


\begin{abstract}
Increased funding pressures on community development and reductions in governmental funding for community support suggest potent roles for philanthropy as a funding source, and the possibility of changing relationships between community development and philanthropy. Focusing on English community foundations and their implementation of the Canadian Vital Signs initiative, which is geared towards assessing communities' vitality and social priorities, our article explores whether, and how, such changes may be occurring.
\end{abstract}

Using the literature on the respective value of 'unsettling' and 'settled' third sector organisations to community development, we reflect on the roles and contributions of community foundations to community development through community philanthropy. Vital Signs reports' content indicates donor-led community philanthropy associated with ameliorative rather than fundamental social change positions, as well as uncertainty surrounding community leadership in this context. We identify community foundations as 'settled' organisations within the community development spectrum and as reflecting the 'directed' community development form. In this instance, it appears that the philanthropycommunity development gap that we suggest is at best being partially bridged. Nevertheless, and paradoxically, these organisations' achievement of financial security through community donorship could also strengthen their community leadership roles in 'unsettling' ways, so doing more to lessen philanthropy and community development's separation. 


\section{Introduction}

Austerity and the abdication of government from many areas of community support place continuing pressure on funding for community development. Among alternative funding sources proposed, such as earned income from social enterprise (Nyssens, 2006) or loaned funds from social investment (Schueth, 2003), philanthropy plays a prominent role. A close association of philanthropy with community development seems, however, tenuous and problematic, with prominent philosophical and operational gaps between the two. Patrician perspectives on philanthropy, that the rich and powerful can tackle social problems more ably than communities themselves (see Carnegie, 1901) contradict the argument that those within communities, those closest to its problems, are positioned uniquely to address these issues, and to do so better than the rich (Layton, 2016 forthcoming). Critics of philanthropic foundations cite the strength of their often disguised power and controlling abilities in society (Roelofs 2003), maintaining systems that sustain "injustices they wish to correct" (Arnove and Pinede, 2007, p.389 ). Yet, foundations have also funded building capacity in community organisations and movements (Faber and McCarthy, 2005; Martinez-Cosio and Bussell, 2012), aligned themselves with social change efforts (Blanke and Walzer, 2012; Doctor, 2014) and helped scale up community activism in areas of community concern, such as energy policy (Bird and Barnes, 2014).

Inter-relations between community development and philanthropy are then a puzzle. Standard accounts of each portray the former as working from the 'ground up', characterised by change, and the latter from the 'top down', characterised by continuity, and so separated by wide gaps. Nevertheless, expectations in both fields of practice, one to seek and use and one to amass and distribute resources effectively, suggest some degree of common cause with philanthropy offering a potent community development funding and leadership source within communities. To what extent and how might philosophical and operational gaps between community development's and philanthropy's goals and practices become bridged and with what results?

In considering these questions, we focus on community foundations, the name of which suggests a combination of the community and philanthropy fields of social action. The community foundation, 'the most identifiable form of structured community philanthropy' (Sacks, 2014, p.3), offers both 'promise' and 'potential' for funding social justice (Ostrander, 
2005, p.47). Characterised as communities' 'agile servants' (Magat, 1989), community foundations attract, manage and disperse funds from multiple (predominantly local) philanthropic sources, for diverse community purposes.

The community foundations' Vital Signs initiative provides a basis to examine more closely community foundations' role within the community development nexus. Pioneered by Canadian community foundations, this was transferred to the UK in 2013/2014 and implemented among selected community foundations. Vital Signs is a mixed community engagement, community leadership and community philanthropy project. It aims to research, discuss, publish and advocate for change around social indicators which measure and grade communities' quality of life. We have chosen Vital Signs as our focus since its intention, simultaneously to drive and help lead social change and attract new community philanthropy by figuratively taking the pulse of local communities, suggests opportunities for particular insights into the state of the gap between community development and philanthropy goals and practice.

Consideration of the respective community development and philanthropy literatures, and the possibilities of commonalities between them, leads us particularly to the literature on third sector organisations' 'settled' and 'unsettling' roles within community development (Kenny, 2011) and to that which identifies a range of more limited to more complete community development types (Matarrita-Cascante and Brennan, 2012). We suggest where community foundations are located in relation to these frameworks and ask what light can be shed on their position by Vital Signs reporting, as an initiative in which community development and philanthropy appear to meet.

We then present illustrative material from selected Vital Signs reports to address three overarching questions: How do community foundations perceive, and organise for, community philanthropy? How, and to what extent, do community foundations facilitate linkages between communities' expressed needs and philanthropic contributions and commitment? What kinds of actions do community foundations take to accompany and further the effects of Vital Signs reporting? Finally, we analyse and reflect on this material, aiming to promote understanding of the nature and state of the community developmentphilanthropy nexus. 


\section{Community development and philanthropy}

Community development and philanthropy both appear as attractive, elusive, and contentious concepts. The community development literature chronicles this field's organisational and goal fluidity as well as its socio-political energy. Broadly aimed at promoting solidarity and agency (Bhattacharyya, 2004), community development has been cast as a triumvirate of 'social support', 'social justice' and 'social capital' (Dolan, 2008), as a process that entails 'organization, facilitation and action which allows people to establish ways to create the community they want to live in' (Matarrita-Cascante and Brennan 2012, p.297). Community leadership is central to this creation: 'leadership within communities of different people who come together in collaborative endeavour' (Kirk and Shutte, 2004, p.237). A 'relational process,' (ibid. p.235), with a key component being 'leading change through dialogue'(ibid., p.239), community leadership is distinguished from person-centred leadership by 'distributed' leadership forms and practice. In the latter, shared, often diverse, leadership contributions are drawn from within and across groups, organisations and networks (Edwards 2011, p.303 ). Implicitly intertwined with participative action, distributed leadership is capable of 'both reflecting and engendering a sense of community among members' (ibid. p. $305)$.

Community development can be veiled in activist, corporatist, even neoliberal, guises (Geoghegan and Powell, 2008). Matarrita-Cascante and Brennan (2012, p.289) distinguish between 'imposed', 'directed' and 'self-help' community development . Respectively, 'imposed' community development occurs where governments or private developers produce improvement to make life better but lacking community involvement; 'directed' community development applies where functional and structural improvements occur via governmental and/or non-governmental organisations, but through community exchange, providing residents with some information and voice; and 'self-help' community development applies where community benefits are associational, with high levels of capacity building and residents taking over directions of change.

This typology draws attention to the enduring question of what counts as community development. Fifty years of CDJ's scrutiny and influence on community development's theory and practice suggests a broad interpretation. Bryant and Oakley (1984, p.214), for 
example, emphasise the importance of recognising 'widely drawn change agents' as 'central to any theory of community development'. Toomey (2011, p.182) draws attention to community development's being 'unfenced', that is, a wide spread of organisations can claim community development roles, subject to the visions of the practising institutions. This suggests too that a range of organisations may claim community leadership, since community leadership's distributed form and practice endorses openness among leadership boundaries and varieties of expertise distributed across the many, not the few (Bolden, 2011).

Conceptualisations of philanthropy are similarly wide-ranging. As the use of private resources - time, treasure, talent - for public benefit and social change, philanthropy covers a spectrum of socio-cultural traditions (Phillips and Jung, 2016 forthcoming). Directions of 'public benefit' and 'social change' are however, unless legally proscribed, matters for donors' choice and one of the key challenges of philanthropy has been donor goal dominance and limited or absent accountabilities (Harrow, 2009,2010). Philanthropic resource provision ranges from 'top down' forms, philanthropic gift-giving, reliant on significant wealth, its inter-generational transmission and control (Reich, 2015), to 'ground up' gift-giving as local communal actions, producing mutual support. This includes, but is not confined to, poor-topoor giving (Wilkinson-Maposa et al, 2005), where the philanthropic act is as important as sums produced. Either way, altruism as a motivation is understood as a philanthropic core (Andreoni, 2006). Community philanthropy, a subcategory within the philanthropy field, encompasses top-down and ground-up giving, as

'the act of individual citizens and local institutions contributing money or goods, along with their time and skills, to promote the well-being of local people and the improvement of the community in which they live and/or work' (European Foundation Centre, 2004,p.5).

Some commentators prefer to talk about place-based philanthropy (Glückler and Ries (2012), drawing on geographical, rather than community, concepts, where geographical proximity is seen to advantage both donor and donee. Glückler and Ries stress that in place-based philanthropy, philanthropic access is not only a matter of proximity but networking - 'being there' and 'being connected' (ibid, p.525). 


\section{Community development and philanthropy: never the twain shall meet?}

Despite limited examples of cross-cutting ideas (e.g. emphasising proximity and networking, discussed above), community development and philanthropy concepts and motivations are deeply contrasting. Their roots appear in opposition. Based respectively in altruism (encouraging paternalism) and solidarity (enabling mutualism), this suggests that "never the twain shall meet'. If this is to change, are there any commonalities to be found?

Literatures on community development and philanthropy, intersecting occasionally, are often exploratory, and contentious about the prospects for synergy. Although both are located in the third sector or civil society space between governments and markets (Henderson and Vercseg, 2010), third sector organisations can be 'top down' and cannot be assumed (or may decline) to share community development values. For example, although Martinez-Cosio and Bussell (2012, p.425) see foundations as among the first 'able to facilitate large-scale urban revitalization in a distressed neighbourhood', if the 'revitalisation discourse' defines the poor as passive and disorganised (Emejulu 2015, p.126), this suggests 'imposed' community development at best - or none.

Nevertheless, some commentators have begun to see some areas of commonality. Batson et al. (2011) incorporate altruistic behaviour within collectivism as motivation to benefit a particular group as whole. Rouf (2014, no pagination) sees community capacity building in Canada and Bangladesh making for 'more altruistic and sustainable local communities'. Adloff (2016 forthcoming) presents altruism as a form of self-sacrificing action, going beyond reciprocity, underpinning both individual generosity and empathetic co-operation that pursues joint projects with common aims. Recent scholarship moreover draws altruism and social solidarity together as a new, combined, field of study (Jeffries, 2014).

The shared third sector focus appears to go beyond the pragmatics of resources needs. A number of the roles ascribed to community development actors by Toomey (2009), going beyond those of 'provider' - rescuer, moderniser, catalyst, facilitator, ally and advocate - are claimed too, by philanthropic actors (Kubisch et al., 2011, Doctor, 2014). In particular, Kenny takes the standpoint that 'much community development discussion' assumes that 'the third sector is the main site within which community development takes place' (2011, p.i8), but draws attention to the lack of critical reflection on third sector organisations' community 
development contributions. Scrutinising whether third sector organisations nurture active citizenship forms appropriate for community development, Kenny (ibid., p.i7) advocates for their 'unsettling' role in power relations, rather than 'settled' roles, of communities' social maintenance and defence. She distinguishes between the 'settled' organisation (maintaining their positions, oriented to social cohesion) and the 'unsettling' organisations, 'never secure and without a comfortable home' (ibid, p. i7-i8). If we consider Kenny's distinction therefore, where might community foundations lie? What light can be shed on their position, by Vital Signs reporting, as an important community philanthropy initiative?

\section{Community foundations as an organisational model and their development in England}

Despite the centenary of community foundations' establishment in Cleveland, USA, in 1914, they appear 'the least studied form of philanthropy' (Sacks, 2014, p.3). One reason for this is the sheer dominance of philanthropic landscapes by very large foundations, funded from strong, narrowly-sourced financial endowments and by internationally-known donors. Another is community foundations' organisational intricacy, with five interrelated purposes, that presuppose organisational 'agility' (Magat, op. cit.) These purposes are: generation of localities' philanthropic resources, financial stewardship of those resources, support services for local donors, grantmaking and programme support for their localities and community leadership (Daly, 2008). Within resources generation, many North American and some European community foundations seek to secure their own financial base through endowment building, which, by its nature, is 'a slow process' (Leat, 2006, p.259). A sense of community foundations' long-term perspective, underpinned by their pro-philanthropy value base is conveyed by their self-assessment of being 'here for good' (Mazany and Perry, 2013). Community leadership is understood broadly to lie in their locally-based and locally-sourced philanthropic expertise (as part of distributed leadership's varieties of expertise, Bolden, op. cit). For Lowe (2004, p.226), their leadership role appears incorporated in, and is demonstrated by, their ability to generate financial resources, as 'mobilising community commitment, increasing resources and enhancing community building skills', seemingly equating community philanthropy and leadership. Easterling (2011), however, notes that leadership can be expressed through undertaking both financial and non-financial roles, the latter including mobilising public attention and shaping policy discourse. 
While community foundations show marked global growth (Community Foundation Atlas, 2014), the community foundation label masks regional contrasts. There are small numbers in some areas, such as East Asia (Wang et al., 2011), and exceptional growth in others, as in Germany (Initiative Bürgerstiftungen, 2015). While North American scholars stress their distinctive multipurpose activities (Graddy and Morgan, 2006, Carman 2001), European commentators highlight their developing civil society/state relations (Walkenhorst, 2008). Community foundations can be found both acting as conduits for government policy (e.g., increased giving in the UK (Pavey et al., 2012)) and challenging government policy (e.g., as in the case of two Egyptian community foundations, that 'adapted their strategies to target political reform' (Herrold, 2012, p. 34)).

Moreover, global growth is not always 'ground-' or even 'middle-up', but rather 'top-down'. Though designed to attract funds from local, often small-scale, middle-, if not ground-, level giving, many community foundations receive funding from leading endowed foundations, that is from 'above'. While this extends community foundations' own resources, it also offers a form of legitimation for those endowed foundations (Leat 2006), using community foundations as community access points. There are very few studies of this philanthropyphilanthropy relationship. However, Brown and Fiester's (2007) major US neighbourhoodbased initiative evaluation contains support for the latter view, reporting community foundations treated as technicians, not fellow change agents, by endowed national foundations.

From this overview, how do community foundations appear, with regard to Kenny's notion of 'settled' and 'unsettling' organisations? Their multi-purpose nature allows for both settling and unsettling organisational types or styles. Insofar as they act as government funding and policy channels, attract community philanthropy for directed projects, become institutionalised ('here for good'), and are conduits for imposed agendas from national endowed foundations, they are settled organisations (with for Kenny, a limited community development contribution). However, that same multipurpose nature and their search for independent funding, (e.g. through endowments) has the potential for 'unsettling' actions.

This sense of potential duality of organisational form is reflected in the development of community foundations in England. With the first community foundation founded in 
Wiltshire in 1975, English community foundations appear partly funded projects of major foundations and successive UK governments, and partly community-grown and developed organisations to 'do community philanthropy' - the latter boosted by increasing policy interest in, and ambition for, localism (Daly, 2008, Jung et al., 2013). There are 48 community foundations across English regions (2015), with Scotland, Northern Ireland and Wales each having one national-level organisation. With annual grantmaking activities of around $£ 65$ million and 'half a billion pounds in endowed funds' (UKCF, 2015, no pagination), UK community foundations are major philanthropy players in their localities (Pharoah, 2011).

The UK community foundations' membership body's view that 'community is a cause' supports community philanthropy's intrinsic community development role, meeting community-expressed and validated resources needs (UKCF, 2014, p.4). Survey research with English community foundation chief executives in 2013 confirmed the importance attached to strengthening community foundations' resource bases, through endowment building and new donor search (Jung and Harrow, 2014). As 'settled' organisations, with potential for 'unsettling' roles in their communities, what increased light can be shed on their positions, by examining Vital Signs reporting as a new community philanthropy initiative? In particular, how do English community foundations perceive, and organise for, community philanthropy? How, and to what extent, do community foundations facilitate linkages between communities' expressed needs and philanthropic contributions and commitment? What kinds of actions do community foundations take to accompany and further the effects of Vital Signs reporting? To examine these questions, we firstly review the nature of the Vital Signs initiative, in its Canadian community foundation origins, and go on to describe and assess English community foundations’ Vital Signs reporting during 2014.

\section{The Canadian Community Foundations' Vital Signs initiative: a meeting of philanthropic and community development minds?}

Since 2001, the Canadian Community Foundations network has run its Vital Signs initiative. This is perceived as a tool and a process for aligning community goal setting 'through a combination of scientific research and public opinion' (CCED, 2015, no pagination). It involves individual community foundations across Canada researching and compiling a range 
of social indicators for their localities. They combine prior, published research on indicators such as health and education with their own community research, with community members and organisations providing perceptions and views, largely through surveys and open invitations. Community members, convened by the community foundations, thus discuss, measure and assign grades to local quality of life indicators. Reports, published annually, in print and digitally, highlight and comment on these indicators, demonstrating communities' vitality and the social and economic trends underlying this. Their dual aim is sustaining local change-directed discussion on findings and attracting new philanthropy in communities to fund that change (Patten and Lyons, 2009).

On the face of things, Vital Signs is a philanthropy-community development meeting of minds. Mutual advantage is sought from multiple community reporting sources and new opportunities for attracting resources, networking and community change. The processes underlying the initiative, however, point to a number of challenges. First of all, while also portrayed modestly as 'annual community check ups', the organisational and community demands of Vital Signs work are significant: to bring existing social data to citizens, enhance citizens' exchanges on community issues, publicise citizens' views, whilst also informing (thereby attracting) local donors in response to community priorities (Patten, 2010). Practical challenges include ensuring data is 'fresh' and 'new' and dependency on media reporting (ibid., no pagination). Secondly, as community involvement is achieved through a variety of means, notably working with other community organisations, it relies on and tests the convening skills and collaborative wills within communities generally, not only within the leading community foundations. Thirdly, its mixed data-gathering approach precludes concentration on participative community based research, though this is often argued as a vital prerequisite for community-led community change (Stoeker, 2009; 2012). Such mixing, though, also reflects a pragmatic approach to capturing communities' vitality, both from communities' own perspectives and as external researchers understand it.

\section{English community foundations and Vital Signs}

Diffusing from Canada, with UK pilot work partly supported by the Hazelhurst Trust, the Community Foundation Tyne \& Wear and Northumberland was the first to publish its own Vital Signs report in May 2013, blending community priorities assertiveness and 
philanthropic outreach. In 2014, ten 'update' reports were published by English community foundations - from Berkshire ('B'), Cambridgeshire ('C'), London's 'East End' ('EE'), Essex ('E'), Hampshire and Isle of Wight ('HIW), Lancashire ('L'), Merseyside ('M') Milton Keynes ('MK'), Tyne \& Wear ('TW'), and Northumberland ('N'). Using complex mixes of national data and local research, drawing in residents' and community organisations' perceptions of 'how things are (or are not) going', these reports provided residents' and community organisations' allocated 'grades' for areas of wellbeing, such as 'work', 'education' and 'arts', blended together by the community foundations to achieve overall views on these localities' Vital Signs.

To explore what these reports might reveal about these community foundations' community development orientations, we used Ritchie and Spencer's (2002) framework approach for qualitative data analysis. Taking a thematic analysis stance, this emphasises a 'systematic process of sifting, charting and sorting material according to key issues and themes' (ibid, p.310). We adapted this to community development by using the framework themes from Matarrita-Cascante and Brennan’s (2012) three procedural elements of community development, that is, 'organisation', 'facilitation' and 'action'. We chose this approach because it differentiates among community development tasks in a manner relevant for organisation practice and can be applied across all three typologised forms - 'imposed', 'directed' and 'self help'.

Focusing on the Vital Signs reports means that our insights are content-based and contextual rather than diagnostic or evaluative. Using our analytical framework, we have identified a series of themes that demonstrate the range and nature of the philanthropy-community interrelation within these reports and the light which these reports shed on the extent to which these community foundations are 'settled organisations' and so limited in their community development contributions.

The themes are presented in the three tables, below. Table 1 demonstrates organisational perspectives and offers answers to our question 'How do community foundations perceive and organise for community philanthropy?'. The second table, addresses the question 'How, and to what extent, do community foundations facilitate linkages between communities' expressed needs and philanthropic contributions and commitments?'. It demonstrates descriptions and analyses of philanthropy-community intermediary and facilitation roles. The 
final table, Table 3, provides illustrations on 'What kinds of actions do community foundations take, to accompany and further the effects of Vital Signs reporting?'. Directed towards the 'action' and community leadership aspects of the community development process, these illustrations suggest more tentative, equivocal perceptions and planned roles than do those in Tables 1 and 2.

Table 1 about here

Table 2 about here

Table 3 about here

\section{Findings}

Our findings show these community foundations' affirmation that their structures and philanthropic purposes ensure significant understanding of, and responsiveness to, their communities' pressures and priorities. They appear as 'top down' and 'bottom up' organisations, seeking community improvement and collaboratively-led interventions. Community philanthropy - using wealth, mainly but not solely local, to change local situations for the better - is held capable of invigoration when evidence of communities' needs and priorities is publicised. Mobilising community responsiveness, incorporating stress on the community foundations' own probity and relative financial security, appears however largely an implicit leadership task.

Reports identified areas of unmet need and chronic concern, citing examples of community foundations' donors' previous interventions and contributions, and commending community foundations' own contributing financial standing and skills. Nevertheless, these interventions 
are of limited kinds. A sense of limitation in what may be achieved in the future is also suggested where reports challenge readers to consider changing community priorities and where a particular community foundation might best concentrate efforts.

This sense of limitation within the community foundations' purposes thus suggests that these reporting community foundations, and the Vital Signs initiative, focus primarily on ameliorative practices. That is, they are not aiming to maintain things wholly as they are (by virtue of highlighting the most problematic Vital Signs). However, they are also not setting out to catalyse fundamental social change. Evidence of disparities of need within the reports' communities leads to them encouraging sense of shared responsibilities one for another, (a form of community altruism perhaps) but not necessarily to transformation.

\section{Discussion}

The analytical framework we used for reviewing Vital Signs reports supports the ameliorative interpretation we suggest. Taking the three procedural elements of community development as 'organisation', 'facilitation' and 'action' (Mataritta-Cascante and Brennan, 2012 ), the greater prominence of organisation and facilitation roles by reporting community foundations, compared to action roles, was striking. The more limited consideration of 'action', cast as ongoing conversations or discussions suggests community foundations' own uncertainty after the high point of reports' publication. Having gone public with Vital Signstype evidence, what are they going to do now, without themselves moving into an 'imposed' mode of community development, discussed above, where community involvement is minimal, muted or absent?

This imbalance towards organisational and away from action practices makes it important to consider the core assumptions of the Vital Signs initiative. The dominant assumption behind the Vital Signs reports as they stand, is that better information will lead to more responsive, hence better, giving in and for communities. Donors' responsiveness will moreover derive from and reflect community - sourced information and community -expressed priorities. However, the main focus in practice has been on establishing or additionally reinforcing community foundations' standing and visibility in their communities, so attracting that giving rather than leading in the sense of initiating community-wide conversations or action. 
This approach in practice still provides opportunity to initiate further dialogue and conversations within communities, so capable of situating community foundations within a model of distributed leadership, with communities empowered in agenda-setting, and taking action in the light of the results of, and community views on, Vital Signs reports. This would be more aligned with community development thinking and has the potential to unsettle. However, Vital Signs reports suggest community foundations' uncertainty about this role, concentrating on organisation and facilitation as precursors to, rather than integrated with, action. The reports do accord value of such conversations, suggesting, too, community foundations' awareness that Vital Signs initiatives cannot, and should not, be progressed by community foundations alone. Nevertheless, the prominence given to community foundations' standing and visibility, together with implications for their relinquishing those positions, cast doubts on whether a distributed leadership (and distributed action) is achievable within Vital Signs work.

Locating community foundations as, at best, within the spectrum of the 'directed' form of community development (Mataritta-Cascante and Brennan, 2012), our findings also demonstrate that form's advantages and disadvantages. These include: seeking limited structural improvements within communities, enabling some community involvement in creating reports, providing residents with (some) information and voice, but not moving (or not able) to move forward to a wholly associational, change-focused approach. Emphasis on their own visibility and standing alone suggests that these community foundations are, or aim to be, far from the 'unsettling' organisations which Kenny (ibid.) seeks among third sector organisations practising community development. Even so, their 'settled' nature, as Kenny recognises, does not preclude them from (an admittedly) limited community development role.

\section{Conclusions}

While central to philanthropy's considerations, questions of 'who pays' seem often to be absent, subdued, or difficult to discuss in the community development field. While Lenette and Ingamells (2015, p.88) have recently drawn attention to the 'growing chasm between funding-driven agencies, and social and community knowledge and practice', we have 
considered whether and how the 'gap' between community development and philanthropy thinking and practice is bridged by English community foundations, and especially as expressed in selected Vital Signs reports.

It is highly unlikely that community philanthropy, as envisaged by community foundations, could, or should, span Lenette and Ingamell's notion of such a chasm. However, global momentum for Vital Signs, for example in Brazil, Bosnia and Herzegovina and Australia, confirms the attraction of developing community-shared knowledge for achieving change. This we would see as a central part of community development 'basics' and an important focus for support for community- focused philanthropy. In the Vital Signs reporting we have studied, moreover, this shared knowledge, because of its community 'pulse-taking' and its capacity to engender shared responsibilities, is importantly linked to relational rather than transactional philanthropic forms (that is, philanthropy as a two-way, mutual interactive relationship between donors and recipient groups, as opposed to a one-way relationship, dominated by donor benevolence).

Our detailed analysis has been based on one set of 'community update' reports in English community foundations only. As such, it offers a partial snapshot. The initiative has the potential to produce community-driven, sanctioned lists of things that donors might fund, but also to extend community foundations' own knowledge (and thus community leadership opportunities), as they themselves become better informed. Both aspects remain to be proven, and evaluation of this initiative among English community foundations will provide an important testing ground.

We find community foundations supportive of community development, by adhering to the importance of giving in and for the communities where they operate, where giving is seen as a critical factor before change occurs, though not the only one. Their community leadership role appears limited predominantly to activating giving, though potentially extended, in distributed form through community dialogues. Thus far then, these community foundations are important players in community change in their localities. Seeking to meet needs in ways validated by the communities where they are situated supports their community values-driven claims, although their parallel emphasis on donors' wishes tempers or diminishes those claims. Paradoxically, securing their own independent financial security, could however free 
them to become 'unsettling' organisations in their own right, supporting community development more thoroughly than their present community philanthropy focus allows.

We recognise the continuing difficulties in our argument for those for whom philanthropycommunity relations remain inevitably and problematically asymmetrical. Drawing attention to major income disparities in localities (as the reports do extensively) is not itself any evidence of solidarity, nor does a declaration about being 'passionate' about a locality offer either necessary solidarity or agency (as if others in the community were themselves any less 'passionate'). Nevertheless, if Mascaritta-Cascante and Brennan's (ibid.) case that all forms of community development have roles to play is accepted, and if 'who pays' in community development is also critical, then community foundations need to be included as among the organisational players. Their approach to, and understanding of, community philanthropy is not wholly equated with community development but is an integral part of community development achievement.

From a community foundations' perspective therefore, we suggest that the philanthropycommunity development gap we have suggested is being accommodated, by no means resolved, but no longer largely unbridgeable. Although we consider community foundations from this study, as 'settled' and thus unchallenging organisations for community development, they also have another 'unsettling' potential. This arises from talking about money, especially philanthropic money, in community development, combined with talking about communities' shared knowledge about their quality of life. It may yet be that the apparently relatively weak Vital Signs reports' subsequent 'conversations' turn out to be among the most unsettling (in the sense of being influential and challenging) part of the process in this initiative and thereby a useful contribution towards bridging the community development-philanthropy gap. 


\section{Authors' biographies}

Jenny Harrow is Professor and Co-Director, Centre for Charitable Giving and Philanthropy (CGAP), Cass Business School, City University London, London, United Kingdom

Tobias Jung is Senior Lecturer, School of Management, University of St. Andrews, St. Andrews, United Kingdom

\section{Funding}

This self-funded research builds on earlier support for the study of community foundations within philanthropy from the UK's Economic and Social Research Council (ESRC), grant reference RES-593-25-0004. 


\section{References}

Adloff, F. (2016 forthcoming) Approaching Philanthropy from a social theory perspective, in T. Jung, S.D. Phillips and J. Harrow, eds, The Routledge Companion to Philanthropy, Routledge, London, in press.

Andreoni, J. (2006) Philanthropy, Handbook of the Economics of Giving, Altruism and Reciprocity, 2, 1201-1269.

Arnove, R., and Pinede, N. (2007). Revisiting the "big three" foundations. Critical Sociology, 33, pp. 389-425.

Batson, C. D., Ahmad, N. and Lishner, D. A. (2011) Empathy and Altruism in eds. C.R. Snyder and S.J. Lopez, The Oxford Handbook of Positive Psychology, Oxford University Press, Oxford, pp. 421-426.

Bhattacharyya, J. (2004) Theorizing community development, Community Development, 34, $5-34$.

Bird, C. and Barnes, J. (2014) Scaling up community activism:the role of intermediaries in collective approaches to community energy, People, Place and Policy Online, 8, no pagination.

Blanke, A.S. and Walzer, N. (2013) Measuring community development: what have we learned? Community Development, 44, 534-550.

Bolden, R. (2011). Distributed leadership in organizations: A review of theory and research. International Journal of Management Reviews, 13, (251-269).

Brown, P. and Fiester, L. (2007) Hard lessons about philanthropy and community change from the Neighborhood Improvement Initiative, The William and Flora Hewlett Foundation,accessed at http://hewlett.org./uploads/files/HewlettNIIReport.pdf (16 February 2014).

Bryant R. and Oakley P. (1984) Community Development and the Role of the Change Agent, Community Development Journal, 19, 214-216.

Carman, J. G. (2001) Community Foundations:A Growing Resource for Community Development,Nonprofit Management and Leadership, 12, 7-24.

Carnegie, A. (1901) The Gospel of Wealth and Other Timely Essays, The Century Co.,New York, NY.

CCED (2015) Vital Signs Project Manager, The Canadian CED Network accessed at: https://ccednet-rcdec.ca/en/job/2015/01/30/vital-signsc-project-manager (17 October 2015). 
Community Foundation Atlas (2014) accessed at: http://communityfoundationatlas.org/ (9 January 2015).

Daly, S. (2008) Institutional innovation in philanthropy: community foundations in the UK, Voluntas: International Journal of Voluntary and Nonprofit Organizations, 19, 219241.

Doctor, L. J.(2014) Philanthropy's role: working alongside communities to support local change, Community Development, 45, 220-226.

Dolan, P. (2008) Social support, social justice, and social capital:a tentative theoretical triad for community development,Community Development, 39, 112-119.

Easterling, D. (2011). Promoting community leadership among community foundations: the role of the Social Capital Benchmark Survey. The Foundation Review, 3, 81-96.

Edwards, G. (2011) Conceptus of Community: A Framework for Contextualizing Distributed Leadership, International Journal of Management Reviews, 13, 301-312.

Emejulu, A. (2015) Community Development as Micro-politics: comparing theories, policies and politics in America and Britain, The Policy Press, Bristol.

European Foundation Centre (2004) Community Philanthropy Watch: Europe 2004. Brussels, accessed

at:http://www.issuelab.org/resource/community_philanthropy_watch_europe_2004, (2 May 2015) .

Faber, D. R. and McCarthy, D. eds (2005) Foundations for social change: Critical perspectives on philanthropy and popular movements, Rowman \& Littlefield, Lanham, MD.

Geoghegan, M. and Powell, F. (2009) Community development and the contested politics of the late modern agora: of, alongside or against neoliberalism?Community Development Journal, 44, 430-447.

Glückler, J.and Ries, M. (2012) Why being there is not enough: organized proximity in place-based philanthropy, The Service Industries Journal, 32, 515-529.

Graddy, E. A. and Morgan, D. L. (2006) Community foundations, organizational strategy, and public policy, Nonprofit and Voluntary Sector Quarterly, 35, 4, 605-630.

Harrow, J. (2009) Donor intent and donor control, in H. Anheier, H. and S.Toepler, eds. International Encyclopedia of Civil Society, Springer, New York, NY, pp.610-616.

Harrow,J. (2010) Philanthropy, in R.Taylor, ed, Third Sector Research, Springer, New York, NY, pp 121-138. 
Henderson, P., and Vercseg, I. (2010). Community Development and civil society: Making connections in the European context. Policy Press, Bristol.

Herrold, C.E. (2012) Philanthropic Foundations in Egypt: Fueling Change or Safeguarding Status quo?, Takaful 2012, Second Annual Conference on Arab Philanthropy and Civic Engagement. Selected Research, June 10 - 12, Cairo, Egypt, pp.30-49.

Initiative Bürgerstiftungen (2015), Zahlen, Daten, Fakten, http://www.buergerstiftungen.org/de/ueber-buergerstiftungen/statistik.html (3 September 2015).

Jeffries, V. ed. (2014). The Palgrave Handbook of Altruism, Morality, and Social Solidarity: Formulating a Field of Study. Palgrave Macmillan, New York, NY.

Jung, T, Harrow, J, and Phillips, S. D. (2013) Developing a better understanding of community foundations in the UK's localisms, Policy \& Politics, 41, 409-427.

Jung, T. and Harrow, J. (2014) 'Cutting off the dead past from the living present?: a critical examination of community foundations in England', paper presented at the 11th International Conference of the International Conference for Third Sector Research, 24 July, 2014, Muenster, Germany.

Kenny, S. (2011) Towards unsettling community development,Community Development Journal 46 (SI), i7-i19.

Kirk, P., and Shutte, A. M. (2004) Community leadership development,Community Development Journal, 39, 234-251.

Kubisch, A., Auspos, P., Brown, P., Buck, E., and Dewar, T. (2011) Voices from the field III:Lessons and challenges for foundations based on two decades of community-change efforts, The Foundation Review, 3, 139-149.

Layton, M.D. (2016 forthcoming) Philanthropy at the Community Level: Supporting Community Empowerment,in T. Jung, S.D. Phillips and J. Harrow, eds, The Routledge Companion to Philanthropy, Routledge, London, in press.

Leat, D. (2006) Foundation legitimacy at the community level in the United Kingdom, in K. Prewitt, M. Dogan, S.Heydemann and S. Toepler,eds, Foundations and the challenge of legitimacy in comparative perspective, Russell Sage Foundation, New York,NY, pp. 252-270.

Lenette, C. and Ingamells, A. (2015) Mind the Gap!The growing chasm between fundingdriven agencies and social and community knowledge and practice, Community Development Journal, 50, 88-103. 
Lowe, J. S. (2004). Community foundations: What do they offer community development?. Journal of Urban Affairs, 26, 221-240.

Magat, R. (1989) An Agile Servant: Community leadership by Community Foundations, Foundation Center, New York, NY.

Martinez-Cosio,M. and Bussell' M.R.(2012) Private foundations and community development:differing approaches to community empowerment,Community Development, 43, 416-42

Matarrita-Cascante, D. and Brennan, M.A. (2012) Conceptualizing community development in the twenty-first century, Community Development, 43, 293-305.

Mazany, T.and Perry, D. C., eds, (2013)Here for Good:Community Foundations and the Challenges of the 21st Century, M.E.Sharpe, Armonk, NY.

Nyssens, M., ed. (2006) Social Enterprise at the crossroads of Market, Public Policies and Civil Society, Routledge,London.

Ostrander, S. A. (2005) Legacy and Promise for Social Justice Funding: Charitable Foundations and Progressive Social Movements, Past and Present,in D.R.Faber and D.McCarthy, eds, Foundations for Social Change: Critical Perspectives on Philanthropy and Popular Movements. Rowman \& Littlefield, Lanham, MD, pp.33- 63.

Patten , M. (2010) Communicating your cause, WINGS Forum 2010, accessed at http://www.wingsweb.org/search/all.asp?bst=Vital+Signs (27 February 2015).

Patten, M. and Lyons, S.(2009) Vital Signs: Connecting Community Needs with Community Philanthropy in Canada, The Philanthropist, 22, 56-61.

Pavey, H.,Harrow, J. and Jung,T. (2012) The role of community foundations in the 'Big Society':taken for granted? in Philanthropy and a Better Society, ESRC Centre for Charitable Giving and Philanthropy, Alliance Trust, London, pp. 75-79.

Pharoah, C. (2011) Charity Market Monitor. Caritasdata, London.

Phillips, S.D. and Jung, T. (2016 forthcoming ) A New 'New' Philanthropy: From Impetus to Impact, in T. Jung, S.D. Phillips, and J. Harrow, The Routledge Companion to Philanthropy, Routledge, London, in press.

Reich, R. (2014). Gift Giving and Philanthropy in Market Democracy, Critical Review, 26, 408-422.

Ritchie, J. and Spencer, L. (2002) Qualitative Data Analysis for Applied Policy Research,in A. M. Huberman and M.B. Miles, eds, The Qualitative Researcher's Companion,Sage, London, pp. 303-330. 
Roelofs, J. (2003). Foundations and public policy: The mask of pluralism, State University of New York Press, New York, NY.

Rouf, K. A. (2014). Community Capacity Building for Eliminating the Individualistic Norms and Values in a Society Polarized by a Socio-Economic Divide. Global Journal of Human-Social Science Research, 14(3)., no pagination, accessed at: http://www.socialscienceresearch.org/index.php/GJHSS/article/viewFile/1193/1134 (27 March 2015)

Sacks, E.W. (2014) The Growing Importance of Community Foundations, The Charles Stuart Mott Foundation and the Lilly Family School of Philanthropy, Indiana University, IND. Schueth, S.(2003) Socially responsible investing in the United States. Journal of Business Ethics, 43, 189-194.

Stoecker, R. (2009) Are we talking the walk of community-based research?. Action Research, 7, 385-404.

Stoecker, R. (2012). Community-based research and two forms of social change. Journal of Rural Social Sciences, 27, 83-98.

Toomey, A. H (2011) Empowerment and disempowerment in community development practice:eight roles practitioners play,Community Development Journal, 46, 181-195.

UKCF (2014) UK Community Foundations Report and Financial Statements 31 March 2014, London, pp.1-29.

UKCF (2015) United Kingdom Community Foundations Network Statistics, accessed at http://ukcommunityfoundations.org/media/network_stats (6 September 2015)

Walkenhorst, P.(2008) From Local Institutions to Transnational Actors: the spread and evolution of the community foundation concept, in Local Mission - Global Vision. Community foundations in the 21st Century. P. D. Hero and P. Walkenhorst,eds, Bertelsmann Stiftung, Gütersloh, Germany.

Wang, L., Graddy, E. and Morgan, D.(2011)The development of community-based foundations in East Asia, Public Management Review, 13, 1155-1178.

Wilkinson-Maposa,S., Fowler, A., Oliver-Evans, C. and Mulenga, C.F.(2005). The Poor Philanthropist: How and why the poor help each other, University of Cape Town School of Business. 


\section{Tables}

\section{Table 1: Community Development Process (i), 'Organisation', by illustrative theme and community foundation report}

\begin{tabular}{|c|c|c|}
\hline Theme & Illustrative extract & $\begin{array}{l}\text { Community } \\
\text { Foundation } \\
\text { Report source }\end{array}$ \\
\hline $\begin{array}{l}\text { 'Top-down', } \\
\text { tidying up } \\
\text { philanthropy }\end{array}$ & $\begin{array}{l}\text { 'community philanthropy ..has a role to play in helping to bridge the } \\
\text { gap between rich and poor by focussing on quality of life for those } 8 \\
\text { living in pockets of deprivation...' }\end{array}$ & $\mathrm{B}$ \\
\hline $\begin{array}{l}\text { 'Philanthropy } \\
\text { first' }\end{array}$ & $\begin{array}{l}\text { '..(this report is) a tool to guide philanthropy, grant making and to } \\
\text { inform local decision making.' }\end{array}$ & $\mathrm{EE}$ \\
\hline $\begin{array}{l}\text { Problem } \\
\text { acceptance } \\
\text { before action }\end{array}$ & $\begin{array}{l}\text { 'Whilst we can celebrate Essex's success we must recognise there are } \\
\text { inequalities that exist across the county. Only by working together can } \\
\text { we ensure everyone can realise their potential' }\end{array}$ & $\mathrm{E}$ \\
\hline \multirow[t]{2}{*}{$\begin{array}{l}\text { Community and } \\
\text { community } \\
\text { valued defined } \\
\text { broadly }\end{array}$} & $\begin{array}{l}\text { 'A feeling of fellowship with others as a result of sharing common } \\
\text { attitudes, interests, and goals.' }\end{array}$ & $\mathrm{M}$ \\
\hline & 'Giving is therefore closely related to social cohesion' & $\mathrm{B}$ \\
\hline \multirow{4}{*}{$\begin{array}{l}\text { Organizational } \\
\text { and financial } \\
\text { credentials } \\
\text { stressed }\end{array}$} & $\begin{array}{l}\text { 'we contacted } 100 \text { local people from the many charities and voluntary } \\
\text { groups we support' }\end{array}$ & $\mathrm{C}$ \\
\hline & $\begin{array}{l}\text { 'we (inspire) people to give and i(are) the leading grant-making } \\
\text { charity in MK, working for and at the heart of Milton Keynes' }\end{array}$ & MK \\
\hline & $\begin{array}{l}\text { 'At a time of transition in the social sector .......we have remained } \\
\text { robust' }\end{array}$ & $\mathrm{M}$ \\
\hline & $\begin{array}{l}\text { 'as a community foundation that manages significant funds on behalf } \\
\text { of local people, businesses, government and other charitable } \\
\text { organisations, we are conducting Vital Signs as a 'check-up' }\end{array}$ & HIW \\
\hline \multirow[t]{2}{*}{$\begin{array}{l}\text { Motivating } \\
\text { passions }\end{array}$} & $\begin{array}{l}\text { 'We are passionate about the East End; we listen to what local people } \\
\text { have to say and want to improve opportunities for those living here' }\end{array}$ & $\mathrm{EE}$ \\
\hline & $\begin{array}{l}\text { 'we connect philanthropists and organisations that have a commitment } \\
\text { and passion for making a difference with Lancashire's social sector, } \\
\text { including vital charities and community groups' }\end{array}$ & $\mathrm{L}$ \\
\hline $\begin{array}{l}\text { Aspirations for } \\
\text { 'Vital Signs' }\end{array}$ & $\begin{array}{l}\text { '....to kick start a conversation about your community philanthropy } \\
\text { (to) help civil society organisations improve community life' }\end{array}$ & TW \\
\hline
\end{tabular}




\begin{tabular}{|l|l|l|}
\hline project & & \\
\cline { 2 - 4 } & $\begin{array}{l}\text { '..(for) ...new kinds of discussions about the issues facing our } \\
\text { communities, allowing us to create a clearer picture and direct our } \\
\text { attention and resources to targeted areas' }\end{array}$ & HIW \\
\hline
\end{tabular}


Table 2: Community Development Process (ii), 'Facilitation', by illustrative theme and community foundation report

\begin{tabular}{|c|c|c|}
\hline Theme & Illustrative extract & $\begin{array}{l}\text { Community } \\
\text { Foundation } \\
\text { Report source }\end{array}$ \\
\hline \multirow[t]{3}{*}{$\begin{array}{l}\text { Central role } \\
\text { of wealth }\end{array}$} & $\begin{array}{l}\text { 'community philanthropy' (is) the use of wealth to address local social } \\
\text { issues' }\end{array}$ & B \\
\hline & $\begin{array}{l}\text { 'We connect people and resources to projects and ideas to create positive } \\
\text { change in our community' }\end{array}$ & MK \\
\hline & $\begin{array}{l}\text { '.... a proud history of community philanthropy - the use of wealth to } \\
\text { address local social problems - is one of Northumberland's greatest } \\
\text { assets. It has a clear role to play in bridging the gap between its residents' } \\
\text { quality of life. }\end{array}$ & $\mathbf{N}$ \\
\hline \multirow{2}{*}{$\begin{array}{l}\text { Donor } \\
\text { prominence } \\
\text { in Vital Signs } \\
\text { reports }\end{array}$} & $\begin{array}{l}\text { '...to better inform our donors about issues and opportunities in the } \\
\text { community; (and) assist us in making connections between individuals } \\
\text { and groups to address those issues' }\end{array}$ & $\mathbf{C}$ \\
\hline & $\begin{array}{l}\text { '(we are) helping them (donors ) to achieve their wishes and make some of } \\
\text { their most important charitable acts and gifts' }\end{array}$ & $\mathbf{L}$ \\
\hline \multirow{4}{*}{$\begin{array}{l}\text { Importance } \\
\text { of generating } \\
\text { new } \\
\text { knowledge }\end{array}$} & $\begin{array}{l}\text { 'when we drill down further we find some of the most disadvantaged } \\
\text { people in the country. The inequalities in our county mask particular } \\
\text { challenges some communities face.......' }\end{array}$ & HIW \\
\hline & $\begin{array}{l}\text { 'There are perhaps two Northumberlands: one characterised by affluence } \\
\text { and a vibrant community life, the other by relative poverty and a raft of } \\
\text { social problems.. Inequality emerges as a key issue for the county' }\end{array}$ & $\mathbf{N}$ \\
\hline & $\begin{array}{l}\text { '(as a) a snapshot of the complex and varied subject of skills and } \\
\text { education in Essex. ..we hope it raises questions and initiates } \\
\text { conversations about what we can do together to help.' }\end{array}$ & $\mathbf{E}$ \\
\hline & $\begin{array}{l}\text { 'we will be addressing our community's vital issues by working } \\
\text { collaboratively with donors and targeting philanthropic resources at } \\
\text { essential local projects' }\end{array}$ & $\mathbf{E E}$ \\
\hline
\end{tabular}


Table 3: Community Development Process (iii), 'Action', by illustrative theme and community foundation report

\begin{tabular}{|c|c|c|}
\hline Theme & Illustrative extract & $\begin{array}{l}\text { Community } \\
\text { Foundation Report } \\
\text { source }\end{array}$ \\
\hline \multirow[t]{3}{*}{$\begin{array}{l}\text { Continuance of } \\
\text { conversations and } \\
\text { challenges }\end{array}$} & $\begin{array}{l}\text { '(this) is just the beginning of an ongoing process of } \\
\text { discussion and, as more people become involved, we expect to } \\
\text { improve our knowledge of what is happening' }\end{array}$ & B \\
\hline & $\begin{array}{l}\text { 'What interest and capacity, if any, does the local charitable } \\
\text { sector have to do more to address the priorities listed (if } \\
\text { additional funding was available)?' }\end{array}$ & $\mathbf{C}$ \\
\hline & $\begin{array}{l}\text { 'Research on the needs of our community would be helpful in } \\
\text { planning new Interventions' }\end{array}$ & $\mathbf{E E}$ \\
\hline \multirow[t]{4}{*}{ Balancing acts } & $\begin{array}{l}\text { 'the needs of residents, local industries and the environment } \\
\text { are not always easily aligned. }\end{array}$ & TW \\
\hline & $\begin{array}{l}\text { 'People were shocked at the } 2013 \text { findings which highlighted } \\
\text { that } 1 \text { in } 5 \text { children in MK live below the poverty line. We } \\
\text { allocated } £ 70,000 \text { of funding for organisations } \\
\text { helping children and families in } M K \text { ' }\end{array}$ & MK \\
\hline & $\begin{array}{l}\text { 'The key to developing participation is promoting the needs } \\
\text { and opportunities for involvement, as well as showing } \\
\text { appreciation to those who serve their community in vital ways' }\end{array}$ & B \\
\hline & $\begin{array}{l}\text { 'Community philanthropy cannot solve this problem (public } \\
\text { sector cuts) but it can do its bit to help at least some } \\
\text { community and voluntary organisations. Local philanthropists } \\
\text { are rising to this challenge' }\end{array}$ & TW \\
\hline
\end{tabular}

